\title{
남성성기능장애의 약물요법
}

\section{양 대 열}

한림대학교 의과대학 강동성심병원 비뇨의학과

\section{Pharmacological management of male sexual dysfunction}

Dae Yul Yang, MD

Department of Urology, Kangdong Sacred Heart Hospital, Hallym University College of Medicine, Seoul, Korea

Male sexual disorders, which are the target of clinical treatment, can be largely divided into erectile dysfunction (ED), ejaculation disorder, infertility, sexual desire disorder, hypogonadism, and other diseases related to penile structure changes, such as Peyronie's disease. Current approaches to ED treatment for most men are based on pharmacotherapy. Pharmacotherapy has evolved since the introduction of papaverine and phenoxybenzamine in the early 1980s. Sildenafil, a phosphodiesterase type 5 inhibitor (PDE5I), was the first approved drug for ED. Currently, PDE5Is are the most widely prescribed drugs and have an overall efficacy of $60 \%$ to $80 \%$ in all categories of ED. Most drugs used in ED are peripheral agents that act on the penis. If a combined treatment with a central nervous system agent and peripheral agents is possible, it may be an effective treatment strategy with higher efficacy. Premature ejaculation (PE) is the most frequent ejaculatory disorder. The absence of a consensus on the definition of PE has served as an obstacle in the investigation of its prevalence and the effectiveness of treatment strategies. Although the etiology of PE is unknown, some biological and psychological hypotheses, including anxiety, penile hypersensitivity, and 5-hydroxytryptamine receptor dysfunction have been suggested. Dapoxetine hydrochloride, a short-acting selective serotonin reuptake inhibitor, was approved for on-demand treatment of PE. Off-label use of antidepressants, topical anesthetic agents, tramadol, and PDE5Is is now available as a pharmacological option. The aim of this review is to describe recent advancements in the pharmacological treatment of male sexual disorders, especially focused on ED and PE.

Key Words: Erectile dysfunction; Premature ejaculation; Pharmacotherapy

\section{서론}

임상적 치료의 대상이 되는 남성의 성기능장애는 크게 발 기부전, 사정장애, 불임, 성욕장애 및 성선기능저하증, 그 외

Received: April 7, 2020 Accepted: May 27, 2020

Corresponding author: Dae Yul Yang

E-mail: yang1408@kdh.or.kr

(C) Korean Medical Association

This is an Open Access article distributed under the terms of the Creative Commons Attribution Non-Commercial License (http://creativecommons. org/licenses/by-nc/3.0) which permits unrestricted non-commercial use, distribution, and reproduction in any medium, provided the original work is properly cited.
페이로니병과 같은 음경의 구조변화와 관련된 질환 등으로 나눌 수 있다. 이 중에서 임상적으로 가장 흔하게 약물치료 의 대상이 되는 질환은 발기부전, 성선기능저하증, 그리고 사정장애의 하나인 조루증이다. 20 세기 중반까지만 하더라 도 이 질환들은 명확한 정의와 구분 없이 광의의 성기능장애 로 분류 및 치료되었으나 1960년대에 이후에 본격전인 분자 생물학의 발전과 호르몬 연구의 발전으로 구분하여 치료할 수 있는 길이 열리게 되었다. 남성의 발기능장애의 경우 임 포텐스와 같은 용어가 혼용되어 사용되었으나 1992년 이후 부터는 발기부전으로 정의되어 사용되기 시작하여 경구약물 의 개발과 함께 치료효과가 비약적으로 개선되었다. 조루증 


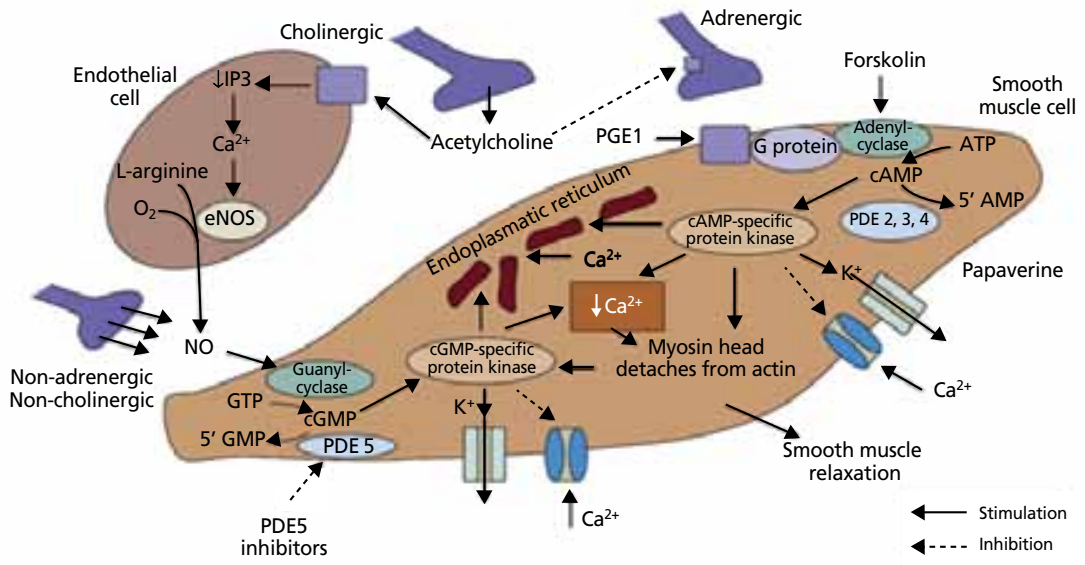

Figure 1. Regulation of penile corpus cavernosum smooth muscle relaxation and effect of phosphodiesterase type 5 (PDE5) inhibitors. ATP, adenosine triphosphate; CAMP, cyclic adenosine monophosphate; CGMP, cyclic guanosine monophosphate; eNOS, endothelial nitric oxide synthase; GTP, guanosine-50-triphosphate; IP3, inositol trisphosphate; NO, nitric oxide; PDE, phosphodiesterase; PGE1, prostaglandin E1. Reproduced from Hatzimouratidis K et al. J Sex Med 2016;13:465-488, with permission from Elsevier [6].

은 남성에서 가장 흔한 사정장애임에도 불구하고 질환의 공 통된 정의가 이루어지지않아 유병률의 조사 및 치료효과 판 정 등에 어려움이 있다. 최근 다폭세틴(dapoxetine)과 같은 약물의 사용이 가능해지면서 질환의 이해 및 치료에 많은 발 전이 이루어지고 있다. 성욕장애 및 성선기능저하증은 아직 은 치료에 대한 논란의 여지가 있을 뿐만 아니라 이 질환만 으로도 내용이 너무 방대하므로 본 종설에서는 발기부전과 사정장애 중 조루와 관련된 약물치료를 중심으로 살펴보도 록 하겠다.

\section{발기부전의 약물치료}

최근의 발기부전 치료는 약물치료를 기반으로 이루어 지고 있다. 발기부전의 약물치료는 1980년대 초반부터 파 파베린(papaverine), 페녹시벤자민(phenoxybenzamine) 과 같은 약제를 사용하게 되면서 본격적인 연구와 약물개 발이 가능하게 되었다[1]. 1990년대 중반에 해면체 주사용 으로 개발된 알프로스타딜(alprostadil)에 이어 PDE5 억제 제(phosphodiesterase type 5 inhibitor)로 최초 개발된 실 데나필(sildenafil)에 의해 발기부전의 본격적인 약물치료가 시작되었다[2,3]. 지금까지 개발된 발기부전 치료제는 작 용부위와 역할에 따라 1) 요힘빈(yohimbine), 아포모르핀

\section{PDE5 억제제}

\section{1) 작용기전}

(apomorphine), 트라조돈(trazodone) 과 같은 중추유발제, 2) 테스토스테론 (testosterone)과 같은 중추조건제, 3) 알프로스타딜(alpro-stadil), PDE5 억 제제와 같은 말초유발제, 4) 유전자치 료, 트라조돈의 일부 역할과 같은 말초 조건제로 분류할 수 있다. 현재 사용되 고 있는 대부분의 약물은 음경에서 작 용하는 말초작용제이다. 중추신경계에 작용하는 일부 약물치료가 시도되었지 만 만족할 만한 임상적인 효과를 얻지 못했거나 사용승인에 실패해서 아직 사 용에는 한계가 있다.

정상적인 발기를 위해서는 성각성이 우선되어야 한다. 분 자생물학적으로 이런 성각성은 음경의 신경말단과 혈관내피 세포에서 산화질소의 합성과 분비로 변환된다. 산화질소의 생성은 L-argininie이 nitric oxide synthase (NOS)에 의해 환원되어 이루어진다, NOS는 neuronal NOS, endothelial NOS, inducibe NOS와 같은 세 가지의 다른 아형을 갖는 효 소 계열이다. 산화질소는 매우 빠르게 해면체 세포내로 분산 유입되어 이차 전달자인 cyclic guanosine monophosphate (cGMP)를 통해 음경해면체 평활근을 이완시키며, 해면체내 로 유입되는 동맥혈류의 증가 및 배출되는 정맥 혈류의 차단 을 통해 발기를 유도한다[4,5]. 이와 같은 음경의 발기 경로 는 $\mathrm{PDE}$ 계열의 효소에 의해 cGMP가 $5^{\prime} \mathrm{cGMP}$ 분해되면 중 단되어 다시 음경은 이완상태로 돌아가게 된다. $\mathrm{PDE}$ 는 최소 11 개의 동종효소를 가지고 있으며 이 중에서 $\mathrm{PDE} 5$ 가 음경 의 발기과정에 가장 중요한 효소로 알려져 있다[1]. 이 효소 의 작용을 억제하면 해면체 세포내 cGMP의 분해가 지연되 어 세포내 농도가 올라가 결과적으로 음경의 발기기능을 보 다 증폭할 수 있다. PDE5 억제제는 직접 발기를 유도하는 물질이 아니며 산화질소의 효과를 강화시켜 간접적으로 발 기를 촉진시킨다(Figure 1) [6]. 이를 위해서는 음경에 충분 
Table 1. Pharmacokinetics of PDE5Is (mean values in fasted state)

\begin{tabular}{lllcc}
\hline \multicolumn{1}{c}{ PDE5I } & $\begin{array}{c}\text { Tmax } \\
(\mathrm{hr})\end{array}$ & $\begin{array}{c}\mathrm{t} 1 / 2 \\
(\mathrm{hr})\end{array}$ & $\begin{array}{c}\text { Cmax } \\
(\mathrm{ng} / \mathrm{mL})\end{array}$ & $\begin{array}{c}\text { AUC } \\
(\mathrm{ng} \cdot \mathrm{hr} / \mathrm{mL})\end{array}$ \\
\hline Avanafil $200 \mathrm{mg}$ & 0.75 & 5.1 & 2,920 & 8,490 \\
Lodenafil $160 \mathrm{mg}$ & 1.2 & 2.4 & 157 & 502 \\
Mirodenafil $100 \mathrm{mg}$ & 1.4 & 2.5 & 2,989 & 7,907 \\
Sildenafil $100 \mathrm{mg}$ & 0.95 & 3.98 & 514 & 1,670 \\
Tadalafil $20 \mathrm{mg}$ & 2 & 17.5 & 378 & 8,066 \\
Vardenafil $20 \mathrm{mg}$ & 0.8 & 4.7 & 31.8 & 96.3 \\
Udenafil $200 \mathrm{mg}$ & 0.76 & 9.88 & $1,136.6$ & 7,898 \\
\hline
\end{tabular}

PDE5I, phosphodiesterase type 5 inhibitor; Tmax, time required for attaining maximum plasma concentration; $\mathrm{t} 1 / 2$, time required for elimination of one half of the inhibitor from plasma; Cmax, maximum plasma concentration; AUC, area under the curve.

한 해면체 조직이 존재해야 하며 성각성과 이로 인한 산화질 소의 생성이 전제되어야 한다.

PDE5 억제제 중에서 실데나필(sildenafil)이 1998년 처음 으로 발기부전 치료제로 상용화되었으며 이어서 2003년에 바데나필(vardenafil), 타다라필(tadalafil)이 사용가능하게 되었다. 국내에서 개발된 유데나필(udenafil)과 미로데나필 (mirodenafil)이 2005년과 2007년에 각각 상용화되었다. 이 어서 2013년 아바나필(avanafil), 로데나필(lodenafil)도 각 각 치료제로 도입되었다.

$\mathrm{PDE} 5$ 유전자는 음경해면체에서 매우 높은 농도로 발현된 다. 하지만, 이 유전자는 고환, 부고환, 정관, 전립선과 같은 생식기뿐만 아니라, 근육, 폐, 위, 갑상선, 부신 등에도 음경 해면체 보다는 낮은 농도로 발현된다[7]. 이와 같은 분포는 $\mathrm{PDE} 5$ 억제제의 부작용과 관련하여 의미가 있다.

\section{2) 약물역동학 및 약역학}

위에서 언급한 PDE5 억제제는 같은 계열의 약물이지만 다른 약물역동학적 특성을 가지고 있다. 필요 시 복용하는 약물의 관점에서 볼 때 복용 후 작용시작 시간을 반영하는 혈 중최대농도 도달시간(time required for attaining maximum plasma concentration, Tmax), 매일 복용요법의 관점에서는 반감기(t1/2)을 근거로 판단할 필요가 있다. 하지만 이는 어디까지나 생체학적 조건이 같은 경우를 전 제한 것이며 앞에서 기술했듯이 음경에 충분한 해면체 조 직이 존재해야 하며 충분한 성각성과 이로 인한 산화질소 의 생성의 조건 충족이 다른 경우에는 의미가 달라진다. 실
데나필, 유데나필, 바데나필, 아바나필은 복용 후 작용시 간을 의미하는 $\operatorname{Tmax}$ 를 기준으로 대체적으로 비슷한 군으 로 분류할 수 있다. 이 중에서 가장 빠른 약제는 아바나필 로 복용 후 15-30분 이내에 성교 시도가 가능하다. 미로 데나필과 로데나필이 그 다음 군, 그리고 타다라필이 작용 시작 시간이 늦은 약제군으로 분류할 수 있다[6]. 임상현장 에서 작용시간 즉 복용 후 효과가 지속되는 시간은 반감기 를 기준으로 판단할 수 있다(Table 1). 위장관 내에서 천천 히 흡수되거나 서서히 분해되는 약의 경우 반감기가 길어 지게 되는데 이 기준에서는 타다라필과 유데나필의 경우 타 약제에 비해 반감기 즉 작용시간이 가장 길다. 국내에서 는 위 두 가지 성분의 약제가 매일 복용요법으로 허가되어 사용되고 있다. 이는 언제든지 원할 때는 성관계를 가질 수 있는 생리적 발기를 목표로 하는 치료전략의 수립에 의미 가 있다고 할 수 있다.

\section{3) 부작용 및 안전성}

부작용에서 약제 간 큰 차이는 없다. PDE5 억제제에 따라 서는 각각 다른 생화학적 선택성을 갖고 있으며 이는 부작용 분포에 대한 또다른 표현이기도 하다. 실데나필과 바데나필 은 망막에 많이 분포하는 $\mathrm{PDE} 6$ 에 대한 교차작용이 상대적으 로 높으며 따라서 시각장애를 일으킬 가능성이 높다. 한편 타 다라필은 $\mathrm{PDE} 11$ 에 대한 교차작용이 상대적으로 높아 이로 인한 근육통 등을 일으킬 가능성이 있음이 제기되고 있다[7].

실데나필의 경우 부작용으로 두통(15.8\%), 얼굴 화끈거림 (10.5\%), 소화장애(6.5\%), 코막힘(4.2\%), 시각장애(2.7\%), 설사 $(2.6 \%)$, 현기증 $(2.2 \%)$, 관절통( $2.0 \%)$ 등이 보고되었 다. 대부분의 PDE5 억제제는 간에서 cytochrome p-450 isoenzyme에 의해 대사되는데, 65 세 이상의 고령으로 이 효 소의 기능이 저하되어 있거나 이 효소를 이용하여 대사되는 시메티딘(cimetidine), 케토코나졸(ketoconazole), 에리쓰로 마이신(erythromycin)과 같은 약제와 병용 투여하게 될 경 우 작용시간이 길어질 수 있다[6].

질산염 복용 환자에게는 병용투여 시 심각한 저혈압이 발 생할 수 있으므로 절대금기로 되어 있다. 질산화물 설하정 을 복용한 환자의 경우 일반적으로 24 시간 이상 경과한 후 에 사용을 권고하며 타다라필과 같이 작용 시간이 긴 약제 
의 경우 좀 더 유의할 필요가 있다. 니코란딜(nicorandil) 역 시 PDE5 억제제와 함께 사용할 경우 혈관평할근의 cGMP 매개에 의한 혈관 이완을 더 증대시킬 위험이 있으므로 병용 투여 금기이다[8]. 알파차단제(alpha blocker)와의 병용은 기립성 저혈압의 위험이 증가하지만 독사조신(doxazosin) 을 제외하고는 저용량부터 시작하여 서서히 증량하면 일반 적으로 안전하다. 심혈관계 부작용에 대해서는 여전히 이견 이 있지만 저혈압, 부정맥, 협심증이 증가한다는 보고가 있 으므로 보다 더 주의를 기울여야 한다[9]. PDE5 억제제 단 독으로 안정성 협심증환자에서 총운동시간, 운동부하 시 심 허혈을 일으키는 시간 등에 영향을 미치는 부작용은 없다. 하지만, 심혈관계 이상을 가진 환자에서는 발기부전 치료 에 앞서 환자의 심장기능이 성행위를 하는데 무리가 없는 지 프린스턴 가이드라인 제 3 판에 의거하여 판단해야 한다 [10]. 성행위는 평지 $1.6 \mathrm{~km}$ 를 20 분 정도에 걷거나 2 층 계 단을 10 초 이내에 걸어 올라가는 것과 같은 6 metabolic equivalent of task (Mets) 이상의 운동을 심장허혈 증상 없이 수행할 경우 저위험군으로 평가하여 성행위를 권할 수 있다. 중위험 군의 경우 부르스 트레드밀(Bruce Treadmill) 프로토콜 4분 정도의 운동량(5-6 Mets)과 같은 것으로 평 가하여 다시 저위험군으로 분류하거나 그렇지 못하면 고위 험군으로 간주하여 심혈관계 전문의의 재평가를 권유한다. 알파차단제와의 병용투여나 조절되지 않는 고혈압 환자에 서도 사용상에 주의해야 한다.

\section{4) 지속사용}

동물실험의 결과 $\mathrm{PDE} 5$ 억제제의 지속적인 사용은 노화, 당 뇨, 수술 등에 의한 음경해면체의 변화를 예방하거나 개선시 킨다는 보고가 있다. 이를 근거로 발기부전의 치료 및 음경재 활치료에 대한 많은 임상연구가 이루어졌으며 그 결과 효용성 과 안정성에 대한 유의한 결과가 보고되어 타다라필과 유데나 필은 국내에서 매일복용 요법이 허가되어 사용되고 있다. 매 일복용요법에 이 부작용 및 안정성 이슈는 필요 시 복용에 비 해 비슷하거나 조금 더 안전한 것으로 조사되었다[11].

\section{5) 임상적 고려점}

대부분의 PDE5 억제제는 비교적 우수한 효능과 안정성을 바탕으로 광범위하게 사용되고 있다. 약제에 따른 개인적인
순응도가 다를 수 있으므로 다양한 약제의 접근, 충분한 적 정용량의 도달이 필요하다. 복용 후 탈락률이 $50 \%$ 나 되므로 비용, 부족한 효용성, 부작용 등의 고려, 자세한 환자의 문진 을 통한 성생활 패턴의 파악이 반드시 전제되어야 한다. 혈 역학 및 역동학적 특징에 따른 고려, 산화질소가 충분히 생 성될 수 있는 성각성, 복용 후 약제 특성에 맞는 작용시작 시 간까지의 충분한 시간, 고지방식품과 같은 흡수를 방해하는 음식이나 술을 피했는지에 대한 검토, 최소 4-10회에 정도 의 충분한 시도가 있었는지 혈중남성호르몬 농도가 낮지 않 은지에 대한 검토도 반드시 전제되어야 한다.

\section{6) 복합요법}

타다라필 $5 \mathrm{mg}$ 매일 복용과 타다라필 $5 \mathrm{mg}$ 매일 복용에 추가로 실데나필 $50 \mathrm{mg}$ 필요 시 복용을 비교한 연구결과 후 자에서 더 유의한 추가적인 효과가 있었으며 부작용 비율은 차이가 없었다. 중등도 이상의 환자의 초기 치료법으로 권장 할 만한다[12,13]. PDE5 억제제 단독요법에서 실패한 환자 에게 해면체주사제와 실데나필 $100 \mathrm{mg}$ 병용요법 시 $31 \%$ 에 서 개선효과가 있었다. 하지만 어지러움증과 같은 부작용도 증가하므로 유의할 필요가 있다[14]. PDE5 억제제 단독요법 에서 실패한 하부요로증상이 동반된 발기부전 환자에서 알 파차단제의 추가가 발기력 개선에 도움이 된다는 연구결과 가 있지만 아직 제한적인 수준이다. 알프로스타딜 요도좌제 와의 병합요법, 스타틴계열의 약물과 병용요법 등도 실험적 으로 시도되고 있다[15]. 성선기능저하증이 있는 환자에서 남성호르몬과 병합요법은 안전하고 효과적인 것으로 알려져 있다. 특히 제 2 형 당뇨, 투석과 신이식을 받은 발기부전 환 자에서 효과적이다.

\section{7) 약제별 간략한 특성}

(1) 실데나필

1998년부터 시판된 가장 먼저 개발된 PDE5 억제제로서 $50,100 \mathrm{mg}$ 이 국내 출시되었으며 서구에서는 $25,75 \mathrm{mg}$ 제 형도 있다. 2012년 특허가 종료되어 필름형, 과립형, 츄정 등 여러 형태의 제형이 개발되어 사용되고 있다. 당뇨, 우울 증, 고혈압, 척추손상, 다발성경화증, 심혈관계질환, 하부요 로증상, 파킨슨씨질환 등과 동반된 발기부전에서 효과가 입 증되었으며, 발기부전 환자의 발기력 향상뿐만 아니라 사회 
심리학적 지표의 개선도 일으킨다. 지금까지 두통, 안면홍 조, 소화장애, 코막힘 등의 순으로 부작용이 나타났으나 대 부분 증등증도 이하로 앞에서 언급한 일반적인 안전성 이슈 와 큰 차이가 없는 비교적 안전한 약제이다[16].

(2) 바데나필

유럽에서 개발되어 2003년부터 시판된 PDE5 억제제로서 약동학적으로 실데나필과 유사하며 $\operatorname{Tmax}$ 가 조금 더 짧은 장점이 있으며 효소아형 선택성에서는 비슷하며 부작용도 비슷한 약제이다. 초기에는 $10,20 \mathrm{mg}$ 기준으로 출시되었다 가 서구에서는 $5 \mathrm{mg}$ 제형이 추가되으며 구강붕해정도 있다. 당뇨성 발기부전에 대한 연구가 많이 이루어졌고 $10 \mathrm{mg}$ 매 일 복용에 추가로 필요 시 $10 \mathrm{mg}$ 복합요법도 의미 있는 결 과를 보고한 바 있다[17].

(3) 타다라필

비아그라에 이어 미국에서 개발되어 2003년부터 시판 된 PDE5 억제제로서 필요 시 복용요법제로 $10,20 \mathrm{mg}$ 이 국내 출시되었으며, 2013년부터 매일 복용요법제로 2.5, $5 \mathrm{mg}$ 제형이 추가되었다. 2015년 특허가 종료되어 필름형, 세립형, 츄정 등 여러 형태의 제형이 현재 국내에 출시되어 있다. 기존 치료법에 반응하지 않은 환자에게 상대적으로 긴 반감기로 인해 매일 복용 혹은 주3회 요법이 가능하게 되었 으며 시간적 제약이 없이 자발적발기가 가능한 치료제로서 일부 개선효과가 입증되었다. 매일 복용요법은 하부요로증 상의 개선 효과, 피나스테라이드(finasteride) 복용 중인 환 자에서도 효과가 있다는 보고가 있다. 타 PDE5 억제제의 일 반적인 부작용 외에 요통, 근육통의 보고가 있다[18].

(4) 유데나필

국내에서 개발된 PDE5 억제제로서 실데나필과 비슷한 약 역동학적 특성을 가지며 반감기가 타다라필 다음으로 길어 서 국내에서는 타다라필과 함께 매일 복용 요법제로 처방되 고 있다. 2005년 첫 발매 당시에는 $100,200 \mathrm{mg}$ 제형이었 으나 추후 연구를 통해 2013년 50, $75 \mathrm{mg}$ 가 추가되어 매일 복용요법에 활용되고 있다. 당뇨, 고혈압이 동반된 발기부전 에 대한 개선효과가 있었으며 사회심리학적 개선효과도 입 증되었다. 부작용은 실데나필과 비슷하지만 국내 연구의 결 과 안면홍조, 두통, 코막힘 등의 순으로 기존의 타 약제들의
서구인 대상으로 한 연구결과인 두통, 안면홍조의 순서와는 조금 차이가 있었다[19].

(5) 미로데나필

국내에서 개발되어 2007년 발매된 미로데나필 역시 기존의 $\mathrm{PDE} 5$ 억제제와 비슷한 약동학적 선택성을 가진다. 50, 100 $\mathrm{mg}$ 제형으로 발매되었으며 2011년부터 구강붕해필름제형으 로 발매되었다. 부작용면에서 기존 약제와 차이가 없다[20].

(6) 아바나필

일본에서 개발되어 우리나라에서 임상연구를 통해 2011 년 $100,200 \mathrm{mg}$ 제형으로 출시된 약물이다. 국가별로는 50 $\mathrm{mg}$ 제형이 출시된 경우도 있다. Tmax가 빠른 장점이 있으 며 주로 필요 시 복용요법으로 사용되는 약제이다. 부작용면 에서 기존 약제와 차이가 없는 것으로 보고되었다[21].

\section{(7) 로데나필}

브라질에서만 사용되는 약제로서 $40,80 \mathrm{mg}$ 로 출시되었 으나 동반질환에 따른 후속 연구가 충분치 못한 관계로 사용 상에 제한이 많은 약제의 수준에 머물러 있다[22].

\section{조루증의 약물치료}

사정과정은 자율신경계 및 체신경계에 의해 누정 및 방 출의 단계로 이루어진다. 정상적인 사정이 일어나기 위해서 는 교감신경, 부교감신경, 체신경의 긴밀한 조화가 필요하 다. 사정반응에는 감각수용체 구심신경경로, 대뇌감각 및 운 동영역, 척수운동중추, 그리고 복합적인 원심신경경로가 관 여한다. 척수에서 사정반사의 조절은 중추신경계통의 각기 다른 수준에서의 신경화학적 통합조절작용을 필요로 한다 [23]. 여기에는 여러 신경전달시스템이 관여하는데 특히 중 추 세로토닌 및 도파민 신경세포가 주된 역할을 하고, 최근 에는 옥시토신 신경세포의 중요성도 부각되고 있다. 그 외 acetylcholine, adrenaline, neuropeptide, GABA, 산화질 소 등이 이차적으로 관여하는 것으로 알려져 있다.

조루증의 병인에 대해서는 아직 밝혀진 게 거의 없다. 불안감과 같은 심리적 요소, 음경 특히 귀두감각 과민, 5-hydroxytryptamine (HT) 수용체 이상 등이 관여하는 것 
Table 2. Pharmacotherapeutic agents for premature ejaculation

\begin{tabular}{|c|c|c|c|c|}
\hline Agent & Recommended dose & $\begin{array}{l}\text { Half-life } \\
\text { (hr) }\end{array}$ & $\begin{array}{l}\text { IELT fold } \\
\text { increase }\end{array}$ & Adverse effect \\
\hline $\begin{array}{l}\text { Dapoxetine (SSRI): } \\
\text { short acting }\end{array}$ & $\begin{array}{c}30-50 \mathrm{mg}, 1-3 \text { hours } \\
\text { before intercourse }\end{array}$ & 1.5 & $2.5-3$ & $\begin{array}{l}\text { Nausea, diarrhea, } \\
\text { headache, somnolence, } \\
\text { dizziness }\end{array}$ \\
\hline Paroxetine (SSRI) & $\begin{array}{l}10-40 \mathrm{mg} / \text { day and } \\
20 \mathrm{mg}, 3-4 \text { hours } \\
\text { prior to intercourse }\end{array}$ & 21 & 11.6 & $\begin{array}{l}\text { Insomnia, anxiety, nausea, } \\
\text { loss of libido, ED, } \\
\text { anhidrosis }\end{array}$ \\
\hline Fluoxetine (SSRI) & 20-40 mg/day & 36 & 5 & $\begin{array}{l}\text { Insomnia, anxiety, nausea, } \\
\text { loss of libido, ED, } \\
\text { anhidrosis }\end{array}$ \\
\hline Sertraline (SSRI) & $\begin{array}{l}50-200 \mathrm{mg} / \text { day and } \\
50 \mathrm{mg}, 4-8 \text { hours prior } \\
\text { to intercourse }\end{array}$ & 26 & 5 & $\begin{array}{l}\text { Insomnia, anxiety, nausea, } \\
\text { loss of libido, ED, } \\
\text { anhidrosis }\end{array}$ \\
\hline $\begin{array}{l}\text { Clomipramine } \\
\text { (TCA) }\end{array}$ & $\begin{array}{c}12.5-50 \mathrm{mg} / \text { day and } \\
25 \mathrm{mg}, 4-24 \text { hours } \\
\text { prior to intercourse }\end{array}$ & $19-37$ & 6 & $\begin{array}{l}\text { Nausea, dry mouth, ED, hot } \\
\text { flushes, arrhythmias }\end{array}$ \\
\hline Tramadol & $\begin{array}{l}25-50 \mathrm{mg}, 3-5 \text { hours } \\
\text { prior to intercourse }\end{array}$ & $5-7$ & $4-7.3$ & $\begin{array}{l}\text { Nausea, dizziness, } \\
\text { insomnia, dyspepsia, } \\
\text { seizures }\end{array}$ \\
\hline PDE5I & $\begin{array}{l}25-100 \mathrm{mg}, \\
30-50 \text { minutes prior } \\
\text { to intercourse }\end{array}$ & $3-6$ & $\begin{array}{l}\text { Monotherapy } \\
\text { has no effect } \\
\text { on IELT }\end{array}$ & $\begin{array}{l}\text { Headache, flushing, } \\
\text { dyspepsia }\end{array}$ \\
\hline $\begin{array}{l}\text { Prilocaine- } \\
\text { lidoocaine topical } \\
\text { cream/aerosols }\end{array}$ & $\begin{array}{l}2.5 \mathrm{~g} \text {, applied } 20- \\
30 \text { minutes prior to } \\
\text { intercourse }\end{array}$ & $1-2$ & $4-6$ & $\begin{array}{l}\text { ED, loss of sensation in } \\
\text { penis and partner's } \\
\text { vagina, skin irritation }\end{array}$ \\
\hline
\end{tabular}

IELT, intravaginal ejaculation latency time; SSRI, selective serotonin reuptake inhibitor; ED, erectile dysfunction; TCA, tricyclic antidepressants; PDE5I, phosphodiesterase-5 inhibitor.

으로 일부 알려진 정도이다. 5-HT1B 및 5-HT2C 자극은 사 정지연, 5-HT1A 수용체의 자극은 사정 촉진을 유도하는 것 으로 알려져 있다. 일차성조루의 경우 중추 및 말초 세로토 닌성, 도파민성, 옥시토신성, 내분비성 인자의 매우 복잡한 상호작용에 의해 매개된다[24]. 이차성조루는 성행위에 대한 불안감, 상대와의 관계 문제와 같은 심리적 문제 또는 발기 부전, 전립선염, 갑상선기능항진증과 같은 동반질환으로 인 해 발생할 수 있다. 나이가 들수록, 비만, 당뇨, 대사증후군, 전립선염, 고프로락틴혈증, 고테스토스테론혈증, 비타민 D와 $\mathrm{B} 12$ 의 결핍증이 있는 환자에서 조루증 발병률이 높다.

조루증은 성인 남성의 20-30\%가 호소할 만큼 흔한 남성 성기능장애이나 아직 공인된 객관적 진단기준이 없어 표준화 된 환자의 진단 및 치료에 어려움이 있다. 그동안 주로 ICD10 또는 $\mathrm{DSM}-\mathrm{IV}$ 와 같은 정신과적인 관점에서 조루증의 진 단기준이 제시되어 이를 주로 임상에 이용하였으나 최근 국 제성의학회에서 1) 질내 삽입 후 1 분 이내에 항상 또는 거의 항상 사정이 일어나고(일차성), 2) 임상적으로 유의미한 불편 감을 느낄 만큼 사정지연 시간이 감소되어 대부분은 3 분 이
내에 사정이 일어나는 경우(후천성), 3) 질내 삽입 시 대부분의 경우 사정을 지 연시킬 수 없으며, 4) 이러한 증상으로 인해 고민하고, 괴롭고, 좌절하여, 결국 성적관계를 기피하는 것과 같은 부정적 인 자존심을 가지게 되는 것이라고 정 의하였다.

최근 추가로 두 가지 조루증후군이 추가되었는데, 변이성 조루는 정상사 정의 한유형으로서 성행위 중 일관성 이 없이 불규칙하게 조기사정이 발생 하며, 주관적 조루는 성관계 동안 일 관성 있게 혹은 일관성이 없더라도 빠 른 사정의 주관적인 인식을 특징적으 로 가진 경우로 사정 지연시간은 정상 범위이거나 심지어 더 오래 지속될 수 있다[25,26].

조루증에 대한 약물치료의 역사 는 1932년 Prajaculin부터 시작되었다. 하지만 오랜 기간 심인성 원인에 의한 증상으로 간주되어 왔고 그 결과 다양 한 심리치료요법이 시도되었지만 주목할 만한 임상적 결 과를 얻지는 못했다. 현재는 선택적 세로토닌재흡수저해제 (selective serotonin reuptake inhibitor, SSRI)와 국소마취 제 성분이 포함된 약제를 이용한 국소 치료가 가장 많이 활 용되고 있으며 새로운 개념의 약물 개발이 활발히 시도되고 있다(Table 2).

\section{SSRI}

\section{1) 다폭세틴}

다폭세틴은 필요 시 복용법(성관계 $1-3$ 시간 전 복용)을 위해 개발된 반감기가 짧은 SSRI 계열의 약제이다. 경구섭 취 1.3 시간(Tmax 1.3시간) 후 최고 혈장농도에 도달하고 $95 \%$ 가 24시간 이내에 체외로 배출된다. 조루증 치료 약제 중 유일하게 다국적 대규모 임상시험을 통해 효과가 입증 된 후에 $30,60 \mathrm{mg}$ 두 가지 용량이 국제적으로 사용되고 있 다. 일차성 및 후천성 조루 모두에서 비슷한 치료효과를 보 
였다. 부작용으로는 오심, 설사, 두통, 어지러움증 등이 용량 의존적으로 나타났다. 혈관미주신경성 실신이 $0.1 \%$ 에서 발 생한다는 보고가 있으므로 이에 대한 유의가 필요하다. 갑자 기 약물 중단하면 금단증세가 나타날 수 있으나 반감기가 짧 은 필요 시 복용제이므로 일반적인 항우울제보다는 안전하 다. PDE5 억제제와 병용투여 시 추가적인 약물 부작용없이 치료만족도를 높이는 것으로 알려져 있으며 저자들은 조루 증 환자를 대상으로 PDE5 억제제(미로데나필)와 병용투여 시 조루증 치료효과가 다폭세틴 단독투여군보다 개선된 결 과를 보고한 바 있다[27].

\section{2) 클로미프라민}

세로토닌성 삼환계 항우울제인 클로미프라민(clomipramine)은 1977년 효과적인 조루증 치료제로 처음 보고되 었다. 최근 연구결과 성관계 2-6 시간 전에 클로미프라민 $15 \mathrm{mg}$ 의 필요 시 복용 위약그룹과 비교하여 유의한 개선효 과가 있는 것으로 보고되었으며 국내에서도 조루치료제로 허가되어 2013년부터 판매 중이다. 가장 일반적으로 보고된 부작용은 $15.7 \%$ 에서 구역질이었고 $4.9 \%$ 에서 현기증이 있었 다. 24 세 이하의 남성에서 초기치료 시에 자살욕구가 증가하 는 위험성이 있으며 3개월 이상 $75 \mathrm{mg}$ 용량 이상으로 사용 하면 칼슘이온 통로를 차단함으로써 정자의 운동과 정관 및 부고환의 수축을 방해할 수 있다[28].

\section{3) 기타 SSRIS}

파록세틴(paroxetine), 써트랄린(sertraline) 등의 약제도 비공식적으로 사용되고 있으며 클로미프라민과 비슷한 효과 를 보이지만 과학적으로 잘 설계된 연구결과가 많지 않아서 제한적 사용에 그치고 있다. 트라마돌(tamamdol) 역시 아편 유사 진통제로서 세로토닌 재흡수 차단효과에 의해 조루증 개선효과를 위해 일부에서 임상연구를 거쳐 일부 사용되고 있으나 효과에 비해 변비, 진정, 구갈, 호흡곤란 약물의존성 발생 가능성 등이 있어 제한적이다[29].

\section{PDE5 억제제}

$\mathrm{PDE} 5$ 억제제에 의한 중추신경계의 교감신경 활성도 감소 와 정관등에 분포한 $\mathrm{PDE} 5$ 수용체를 통한 평활근이완 효과 에 의해 조루증 치료에도 적용하려는 연구가 많이 진행되었
다. 지금까지 보고된 결과들을 종합하여 보면 일차성 조루증 에서 PDE5 억제제 단독요법보다는 다폭세틴과 같은 SSRI 들과 병합투여가 좀 더 합리적이다. 발기부전에 따른 이차성 조루에서는 단독요법으로 이용될 수 있다[30,31].

\section{3. 국소도포제}

음경 귀두의 감각이 지나치게 예민하여 조루증이 발생한다 는 가설에 근거한 치료법으로 lidocaine이나 prilocaine을 기 반으로 크림, 겔, 분무 등의 형태로 판매되고 있다. 귀두의 감 각 예민에 의해 조루증이 발생한 한정된 환자군에서는 오래전 부터 사용되어 왔으나 치료효과를 객관적으로 입증할 수 있는 무작위 대조시험들의 결과가 충분치 않은 단점이 있으며 경 구약물에 비해 전신 부작용이 거의 없다는 장점이 있다[32].

\section{1) EMLA (eutectic mixture of local anesthetics) 크림}

$2.5 \mathrm{mg}$ 크림에 lidocaine과 prilocaine이 각각 2.5\%씩 함 유되어 있다. 성교 10-20분 전에 음경의 체부와 귀두부에 도포 후 씻어 낸 후 사용한다. 크림을 도포한 채 45 분 이상 지나면 음경 감각이 일시적으로 마비될 수 있으며 질내 삽입 전에 약물이 제거되지 않으면 오히려 상대 여성의 성적 감각 을 억제할 가능성이 있다.

\section{2) SS 크림}

국내에서 개발된 약제로 인삼, 당귀, 육종용, 사살자, 산초, 계피, 세신, 정향, 섬수 등 국소마취와 혈관 확장효과가 있는 9 가지 생약유효성분 추출 복합물로 이루어진 약제이다. 국내 연구진이 주도한 여러 임상을 통해 효과가 입증되었다. 역시 도포 후 성행위 전에 씻어내야 하는 번거로움, 경미한 통증 및 국소 작열감, 고유의 냄새 등으로 널리 사용되지 못하고 있다.

\section{3) TEMPE}

TEMPE (topical eutectic mixture for premature ejaculation)은 1 회 분무 기준 $7.5 \mathrm{mg}$ 의 lidocaine과 $2.5 \mathrm{mg}$ 의 prilocaine이 함유된 분무형 제제이다. 성교 10-15분 전에 귀두에 평균 3 회 분무하며 효과가 빠른 장점이 있다. 음경감 각이 지나치게 둔화되는 크림의 단점을 개선하기 위해 고안된 약제로 현재 유럽에서 승인되어 사용중인 약제이다. 부작용 비율은 국소감각저하(4.5\%), 발기부전(4.4\%), 여성에서 음부 의 회끈거림(3.9\%), 감가저하(1.0\%) 등으로 보고되었다[33]. 


\section{4. 개발중인 약제들}

사정 반사에서 중심성 옥시토신 수용체의 중요성을 고려하 여 몇몇 연구자들은 조루 치료에서 옥시토신 수용체 길항제의 효능과 안전성을 평가하여 epelsiban과 cligosiban과 같은 약 제들이 개발 중에 있으며 사정을 지연시키는데 안전하고 효 과적임이 밝혀졌지만 추가연구가 진행 중인 상태이다[34,35].

\section{결론}

산화질소의 혈관 평활근에 대한 역할의 발견 이후 발기부 전치료에 대한 약물개발은 비약적으로 발전했다. $\mathrm{PDE} 5$ 억 제제는 발기부전의 원인이 되는 동반 질환의 카테고리에 관 계없이 60-80\% 환자에서 효과가 있다. 하지만 지금까지 개 발되어 사용되는 대부분의 약제는 국소촉진제로서 중추신경 계에 안전하고 효과적으로 작용하는 중심성 치료제의 개발 은 아직 답보상태이다. 중심성 치료제와 말초 지료제의 복합 치료요법의 사용이 가능해질 때 발기부전의 약물치료는 한 단계 더 진전할 것으로 기대한다. 조루증은 증상을 호소하는 환자에 비해 질환으로 인식하여 치료를 구하는 환자의 비율 이 낮은 단계인데 이는 20 년전 $\mathrm{PDE} 5$ 억제제가 처음 출시되 었을 때 발기부전의 경우와 비슷하다. 조루증의 정의 및 치 료평가 방법이 이제 구축된 단계로 앞으로 일차성, 후천성 조루뿐만 아니라 변이성, 주관적 조루증에 대해서도 구분하 여 치료할 수 있는 약제가 개발될 수 있기를 기대한다.

\section{찾아보기말: 발기부전; 조루증; 약물요법}

\section{ORCID}

Dae Yul Yang, https://orcid.org/0000-0002-7331-302X

\section{Conflict of Interest}

No potential conflict of interest relevant to this article was reported.

\section{References}

1.Eardley I, Donatucci C, Corbin J, El-Meliegy A, Hatzimou- ratidis $\mathrm{K}$, McVary K, Munarriz R, Lee SW. Pharmacotherapy for erectile dysfunction. J Sex Med 2010;7:524-540.

2.Hatzimouratidis K, Amar E, Eardley I, Giuliano F, Hatzichristou D, Montorsi F, Vardi Y, Wespes E; European Association of Urology. Guidelines on male sexual dysfunction: erectile dysfunction and premature ejaculation. Eur Urol 2010;57:804814.

3.Lue TF. Erectile dysfunction. N Engl J Med 2000;342:18021813.

4. Francis SH, Colbran JL, McAllister-Lucas LM, Corbin JD. Zinc interactions and conserved motifs of the cGMP-binding cGMP-specific phosphodiesterase suggest that it is a zinc hydrolase. J Biol Chem 1994;269:22477-22480.

5. Francis SH, Lincoln TM, Corbin JD. Characterization of a novel cGMP binding protein from rat lung. J Biol Chem 1980;255:620-626.

6. Hatzimouratidis K, Salonia A, Adaikan G, Buvat J, Carrier S, El-Meliegy A, McCullough A, Torres LO, Khera M. Pharmacotherapy for erectile dysfunction: Recommendations from the Fourth International Consultation for Sexual Medicine (ICSM 2015). J Sex Med 2016;13:465-488.

7.Bruzziches R, Francomano D, Gareri P, Lenzi A, Aversa A. An update on pharmacological treatment of erectile dysfunction with phosphodiesterase type 5 inhibitors. Expert Opin Pharmacother 2013;14:1333-1344.

8. Satake N, Zhou Q, Morikawa M, Inoue M, Shibata S. Potentiating effect of nicorandil, an antianginal agent, on relaxation induced by isoproterenol in isolated rat aorta: involvement of cyclic GMP-inhibitable cyclic AMP phosphodiesterase. J Cardiovasc Pharmacol 1995;25:489-494.

9.Corona G, Razzoli E, Forti G, Maggi M. The use of phosphodiesterase 5 inhibitors with concomitant medications. J Endocrinol Invest 2008;31:799-808.

10.Nehra A, Jackson G, Miner M, Billups KL, Burnett AL, Buvat J, Carson CC, Cunningham GR, Ganz P, Goldstein I, Guay AT, Hackett G, Kloner RA, Kostis J, Montorsi P, Ramsey M, Rosen R, Sadovsky R, Seftel AD, Shabsigh R, Vlachopoulos C, $\mathrm{Wu}$ FC. The Princeton III Consensus recommendations for the management of erectile dysfunction and cardiovascular disease. Mayo Clin Proc 2012;87:766-778.

11.Porst H, Gacci M, Büttner H, Henneges C, Boess F. Tada-lafil once daily in men with erectile dysfunction: an integrated analysis of data obtained from 1913 patients from six randomized, double-blind, placebo-controlled, clinical studies. Eur Urol 2014;65:455-464.

12.Buvat J, Büttner $\mathrm{H}$, Hatzimouratidis K, Vendeira PA, Moncada I, Boehmer M, Henneges C, Boess FG. Adherence to initial PDE-5 inhibitor treatment: randomized open-label study comparing tadalafil once a day, tadalafil on demand, and sildenafil on demand in patients with erectile dysfunction. J Sex Med 2013;10:1592-1602.

13.Cui H, Liu B, Song Z, Fang J, Deng Y, Zhang S, Wang H, Wang Z. Efficacy and safety of long-term tadalafil $5 \mathrm{mg}$ once daily combined with sildenafil $50 \mathrm{mg}$ as needed at the early stage of treatment for patients with erectile dysfunction. Andrologia 2015;47:20-24.

14.McMahon CG, Samali R, Johnson H. Treatment of intracorporeal injection nonresponse with sildenafil alone or in 
combination with triple agent intracorporeal injection therapy. J Urol 1999;162:1992-1997.

15.Moncada I, Martinez-Salamanca J, Ruiz-Castane E, Romero J. Combination therapy for erectile dysfunction involving a PDE5 inhibitor and alprostadil. Int J Impot Res 2018;30:203208.

16.Goldstein I, Lue TF, Padma-Nathan H, Rosen RC, Steers WD, Wicker PA. Oral sildenafil in the treatment of erectile dysfunction. Sildenafil Study Group. N Engl J Med 1998; 338:1397-1404.

17.Chung E, Broc GB. A state of art review on vardenafil in men with erectile dysfunction and associated underlying diseases. Expert Opin Pharmacother 2011;12:1341-1348.

18.Seftel A, Goldfischer E, Kim ED, Dula E, Zeigler H, Burns P. Onset of efficacy of tadalafil once daily in men with erectile dysfunction: a randomized, double-blind, placebo controlled trial. J Urol 2011;185:243-248.

19.Zhao C, Kim SW, Yang DY, Kim JJ, Park NC, Lee SW, Paick JS, Ahn TY, Min KS, Park K, Park JK. Efficacy and safety of once-daily dosing of udenafil in the treatment of erectile dysfunction: results of a multicenter, randomized, doubleblind, placebo-controlled trial. Eur Urol 2011;60:380-387.

20.Paick JS, Ahn TY, Choi HK, Chung WS, Kim JJ, Kim SC, Kim SW, Lee SW, Min KS, Moon KH, Park JK, Park K, Park NC, Suh JK, Yang DY, Jung HG. Efficacy and safety of mirodenafil, a new oral phosphodiesterase type 5 inhibitor, for treatment of erectile dysfunction. J Sex Med 2008;5:2672-2680.

21.Wang R, Burnett AL, Heller WH, Omori K, Kotera J, Kikkawa K, Yee S, Day WW, DiDonato K, Peterson CA. Selectivity of avanafil, a PDE5 inhibitor for the treatment of erectile dysfunction: implications for clinical safety and improved tolerability. J Sex Med 2012;9:2122-2129.

22.Glina S, Fonseca GN, Bertero EB, Damiao R, Rocha LC, Jardim CR, Cairoli CE, Teloken C, Torres LO, Faria GE, da Silva MB, Pagani E. Efficacy and tolerability of lodenafil carbonate for oral therapy of erectile dysfunction: a phase III clinical trial. J Sex Med 2010;7:1928-1936.

23. Chung WS. Pharmacological management of male sexual dysfunction. J Korean Med Assoc 2008;51:770-778.

24.Giuliano F. 5-Hydroxytryptamine in premature ejaculation: opportunities for therapeutic intervention. Trends Neurosci 2007;30:79-84.

25.Waldinger MD, Schweitzer DH. The use of old and recent DSM definitions of premature ejaculation in observational studies: a contribution to the present debate for a new classification of PE in the DSM-V. J Sex Med 2008;5:1079-1087.

26. Waldinger MD, Schweitzer DH. Method and design of drug treatment research of subjective premature ejaculation in men differs from that of lifelong premature ejaculation in males: proposal for a new objective measure (part 1). Int J Impot Res 2019;31:328-333.

27.McMahon CG, Althof SE, Kaufman JM, Buvat J, Levine SB, Aquilina JW, Tesfaye F, Rothman M, Rivas DA, Porst H. Efficacy and safety of dapoxetine for the treatment of premature ejaculation: integrated analysis of results from five phase 3 trials. J Sex Med 2011;8:524-539.

28.Choi JB, Kang SH, Lee DH, Kim YS, Jeon JS, Choi WS, Kim SW. Efficacy and safety of on demand clomipramine for the treatment of premature ejaculation: a multicenter, randomized, double-blind, phase III clinical trial. J Urol 2019;201:147-152.

29.Kirby EW, Carson CC, Coward RM. Tramadol for the management of premature ejaculation: a timely systematic review. Int J Impot Res 2015;27:121-127.

30.Lee WK, Lee SH, Cho ST, Lee YS, Oh CY, Yoo C, Cho JS, Lee SK, Yang DY. Comparison between on-demand dosing of dapoxetine alone and dapoxetine plus mirodenafil in patients with lifelong premature ejaculation: prospective, randomized, double-blind, placebo-controlled, multicenter study. J Sex Med 2013;10:2832-2841.

31.McMahon CG, Stuckey BG, Andersen M, Purvis K, Koppiker N, Haughie S, Boolell M. Efficacy of sildenafil citrate (Viagra) in men with premature ejaculation. J Sex Med 2005;2:368-375.

32.Busato W, Galindo CC. Topical anaesthetic use for treating premature ejaculation: a double-blind, randomized, placebocontrolled study. BJU Int 2004;93:1018-1021.

33.Porst H, Burri A. Fortacin spray for the treatment of premature ejaculation. Urologia 2017;84(2 Suppl):1-10.

34.McMahon C, Althof S, Rosen R, Giuliano F, Miner M, Osterloh IH, Muirhead GJ, Harty B; PEPIX Multi-Centre Study Group. The oxytocin antagonist cligosiban prolongs intravaginal ejaculatory latency and improves patientreported outcomes in men with lifelong premature ejaculation: results of a randomized, double-blind, placebo-controlled proof-of-concept trial (PEPIX). J Sex Med 2019;16:11781187.

35.Shinghal R, Barnes A, Mahar KM, Stier B, Giancaterino L, Condreay LD, Black L, McCallum SW. Safety and efficacy of epelsiban in the treatment of men with premature ejaculation: a randomized, double-blind, placebo-controlled, fixed-dose study. J Sex Med 2013;10:2506-2517.

\section{Peer Reviewers' Commentary}

이 논문은 가장 대표적인 남성성기능장애인 발기부전과 조루 증의 약물치료에 대하여 최신 지식을 정리하여 소개해 주고 있 다. 대표적인 경구용 치료약물인 phosphodiesterase type 5 (PDE5) 차단제의 종류, 효과 및 부작용을 잘 설명하고 있다. 조 루증은 자율신경계 및 체신경계의 비정상적 사정 반사, 세로토 닌 수용체 이상, 불안감과 같은 심리적 요소, 음경 귀두 감각 과 민 등이 관여하는 것으로 알려져 있다. 조루증 치료제로는 세 로토닌 양을 조절하는 selective serotonin reuptake inhibitor (SSRI)가 권장되며, 발생 원인에 따라 PDE5 차단제, 국소마취 제 성분이 포함된 약제 등을 사용하여 삶의 질을 높일 수 있음 을 제시하고 있다. 이 논문은 진료 현장에서 남성 성기능장애 인 발기부전과 조루증을 치료하는 데 있어 많은 도움이 될 것 으로 판단된다.

[정리: 편집위원회] 